\title{
Probability of Liquefaction for Pit Disassembly and Conversion Facility (PDCF) Site, Savannah River Site (U)
}

By

R. C. Lee, M. D. McHood and M. R. Lewis

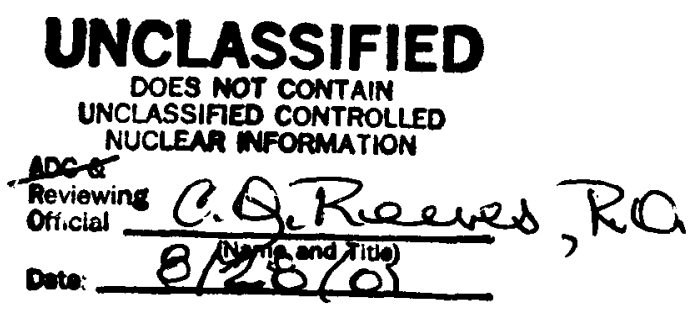

Westinghouse Savannah River Co. Savannah River Site Site Geotechnical Services Aiken, SC 29808 
This document was prepared in conjunction with work accomplished under Contract No. DE-AC09-96SR18500 with the U. S. Department of Energy.

\section{DISCLAIMER}

This report was prepared as an account of work sponsored by an agency of the United States Government. Neither the United States Government nor any agency thereof, nor any of their employees, makes any warranty, express or implied, or assumes any legal liability or responsibility for the accuracy, completeness, or usefulness of any information, apparatus, product or process disclosed, or represents that its use would not infringe privately owned rights. Reference herein to any specific commercial product, process or service by trade name, trademark, manufacturer, or otherwise does not necessarily constitute or imply its endorsement, recommendation, or favoring by the United States Government or any agency thereof. The views and opinions of authors expressed herein do not necessarily state or reflect those of the United States Government or any agency thereof.

This report has been reproduced directly from the best available copy.

Available for sale to the public, in paper, from: U.S. Department of Commerce, National Technical Information Service, 5285 Port Royal Road, Springfield, VA 22161, phone: (800) 553-6847, fax: $(703) 605-6900$

email: orders@ntis.fedworld.gov

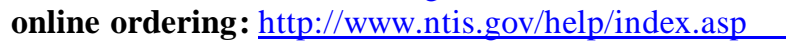

Available electronically at http://www.osti.gov/bridge

Available for a processing fee to U.S. Department of Energy and its contractors, in paper, from: U.S. Department of Energy, Office of Scientific and Technical Information, P.O. Box 62, Oak Ridge, TN 37831-0062,

phone: (865)576-8401,

fax: (865)576-5728

email: $\underline{\text { reports@ adonis.osti.gov }}$ 
This page intentionally left blank 


\section{LIST OF ACRONYMS}

CPT cone penetrometer testing

CPTU piezocone penetration test sounding

SCPTU seismic piezocone penetration test sounding

CSR cyclic stress ratio $\left(\tau_{\text {ave }} / \sigma_{\mathrm{v}}^{\prime}\right)$

CSRN cyclic stress ratio normalized to magnitude

CRR cyclic resistance ratio

DOE United States Department of Energy

EPRI Electric Power Research Institute

$\tau_{\text {ave } \quad \text { effective shear stress }}$

$\sigma_{\mathrm{v}}^{\prime} \quad$ effective overburden pressure

GSA General Separations Area

LLNL Lawrence Livermore National Laboratory

MFFF MOX Fuel Fabrication Facility

M-bar average earthquake magnitude

$\mathrm{N}_{60}$

standard penetration blowcount normalized to $60 \%$ energy

$\left(\mathrm{N}_{1}\right)_{60}$ standard penetration blowcount normalized for overburden pressure and $60 \%$ energy

OCR overconsolidation ratio

PDCF Pit Disassembly and Conversion Facility

PGA peak ground acceleration

POL probability of liquefaction

POO probability of occurrence

PSHA probabilistic seismic hazard assessment

SGS Site Geotechnical Services

SPT standard penetration test

SRS Savannah River Site

USGS United States Geological Survey

WSRC Westinghouse Savannah River Company 


\subsection{INTRODUCTION}

This report documents the probability of liquefaction (POL) for the Pit Disassembly and Conversion Facility (PDCF). The procedure and methodology used in this evaluation is consistent with the POL evaluation for H-Area documented in WSRC (2000a) and for F-Area and the Mox Fuel Fabrication Facility (MFFF), documented in WSRC (2001a). As outlined in these reports, the procedure for analysis of a critical layer of interest requires the following basic steps: (1) establish the probability of occurrence (POO) of ranges of $2.5 \mathrm{~Hz}$ bedrock motion based on a probabilistic seismic hazard assessment (PSHA); (2) define the critical layer that may be susceptible to liquefaction; (3) estimate distributions of cyclic stress ratio (CSR) (i.e., seismic demand) for the critical layer using site-specific soil properties corresponding to the bedrock motions; (4) estimate capacity $\left(\left(\mathrm{N}_{1}\right)_{60}\right)$ of the critical layer based on site-specific cone penetration test(CPT) soundings and standard penetration test (SPT) blowcount data; and (5) sum the probability of liquefaction for each range of bedrock motion using empirical data correlating demand and capacity with liquefaction.

Three bedrock outcrop PSHAs were used for this analysis: (1) Electric Power Research Institute (EPRI) (NEI, 1994); (2) Lawrence Livermore National Laboratory (LLNL) (Bernreuter, 1997); and (3) the United States Geological Survey (USGS) (Frankel, 1999). Each of these PSHAs include a complete hazard disaggregation comprised of percentage hazard by earthquake magnitude and distance bins for each level of bedrock motion. POL estimates are derived for each of the PSHAs.

The soil layer most susceptible to liquefaction is the critical layer. The critical layer is characterized by relatively low blowcount and low fines content and is established from soil layers below the water table.

A key component for seismic demand is the establishment of the soil profile and it's uncertainty. The PDCF site is consistent with the 1997 SRS-specific model used to compute the site amplification database (LawGibb, 2001). Thus, previously derived site amplification functions reflecting the uncertainty in site properties and stratigraphy can be used to predict distributions of CSR given a specific earthquake magnitude and level of bedrock motion. The previously developed site amplification database reflects uncertainty in site response based on the large database of site shear-wave velocity profiles (WSRC, 1997). Consequently, for each level of bedrock motion (from the PSHA) the site amplification database is used to establish the distribution of the expected CSR (demand) in the critical layer.

Soil capacity is determined from the measured or inferred distribution of Standard Penetration Test (SPT) blow-count data $\left(\left(\mathrm{N}_{1}\right)_{60}\right)$. Soil capacity is inferred from direct SPT measurements of $\left(\mathrm{N}_{1}\right)_{60}$. In addition to the more costly SPT measurements, $\left(\mathrm{N}_{1}\right)_{60}$ is also estimated from the more economical and abundant existing CPTU soundings conducted in the study area. For the PDCF site, the distributions on $\left(\mathrm{N}_{1}\right)_{60}$ derived from SPT and CPTU measurements are processed independently in the POL analyses. Geotechnical data for the PDCF site include recently collected and historic data (WSRC, 2001b; 2001c). 
Given the critical layer seismic demand and soil capacity, the liquefaction probability is determined using empirical relationships derived by Liao et al. (1988). The Liao et al. (1988) relationships require a normalized CSR or CSRN (normalized for earthquake magnitude). In addition to the magnitude scaling factor, corrections are also applied to correct for the age of the deposit, overconsolidation ratio and sample handling. Based on the PSHA, the computed CSRs have earthquake magnitude and distance functionality for any given bedrock motion.

As shown in the methodology section below, the POL is summed for each level of bedrock motion. Because the DOE uses three PSHAs for the SRS, the mean POL is taken. A similar analysis was conducted for H-Area (WSRC, 2000a) and F-Area and MOX (WSRC, 2001a). The $\mathrm{H}$-Area study resulted in a mean annual POL of about $4.3 \times 10^{-5}$ (geometric mean of $2.4 \times 10^{-5}$ ) for the Tobacco Road formation. The F-Area study resulted in a mean annual POL of about $1.8 \times 10^{-5}$ (geometric mean about $9.7 \times 10^{-6}$ ) for F-Area and a mean annual POL of bout $3.6 \times 10^{-5}$ (geometric mean about $1.9 \times 10^{-5}$ ) for MFFF. Although the data analysis is similar between the areas, the depth of the critical layer and water table are significantly greater in F-Area than in H-Area.

Note that the POL for F-Area is an area-wide average and therefore cannot be used for any sitespecific application. The POL for the MFFF site is a site-specific average value, as is the POL discussed herein for the PDCF. The liquefaction probability assessments for any other facility location in F-Area will require a site-specific assessment.

\subsection{SCOPE}

The specific scope of the work included the following for the PDCF site:

- Review and assess site-specific stratigraphy.

- Determine site-specific ground water table.

- Determine depth and strength of the critical layer.

- Compute a mean annual POL using EPRI, LLNL and USGS PSHAs.

\subsection{METHODOLOGY}

\subsection{Evaluation of Probability of Liquefaction}

The basic methodology used for this assessment is described in WSRC (2000a). The methodology was developed to evaluate the probability of liquefaction (POL) of a subsurface soil layer or formation. That methodology uses a PSHA evaluated for bedrock outcrop, a determination of seismically induced cyclic stress ratios (CSR) for the soil layer or formation using a suite of convolution analyses from bedrock, an evaluation of the distribution of normalized SPT blowcount (i.e., $\left.\left(\mathrm{N}_{1}\right)_{60}\right)$ for the soil layer or formation and the POL given seismically induced CSR and normalized blowcount available in the literature. 
The POL is obtained by evaluating the probability of occurrence of specific earthquakes and the probability of liquefaction given the occurrence of a specific earthquake. Given those evaluations, the probability of liquefaction for a specific earthquake is:

$$
\mathrm{P}_{\mathrm{E}}(\mathrm{L})=\mathrm{P}[\mathrm{L} \mid \mathrm{E}] \mathrm{P}[\mathrm{E}]
$$

Where $P_{E}(L)$ is the probability of liquefaction as a result of an earthquake; $P[L \mid E]$ is the conditional probability of liquefaction given that the earthquake occurs; and $\mathrm{P}[\mathrm{E}]$ is the probability that the earthquake occurs. The total overall POL is obtained by summing over all possible earthquakes, as follows:

$$
\mathrm{P}[\mathrm{L}]=\sum_{E} \mathrm{P}[\mathrm{L} \mid \mathrm{E}] \mathrm{P}[\mathrm{E}]
$$

The methodology presented herein uses the model for conditional probability of liquefaction developed by Liao, et al, (1988). The model was developed based on statistical analyses of a data catalog consisting of 278 observed cases of liquefaction/no liquefaction in Holocene deposits, for 40 earthquakes. The Liao et al. (1988) models for clean and silty sand are shown in Figures 1a and $1 b$.

From the Liao et al. (1988) model, the probability of liquefaction can be obtained once the normalized standard penetration test blowcount $\left(\mathrm{N}_{1}\right)_{60}$ and the normalized cyclic stress ratio $(\mathrm{CSRN})$ are known. For this assessment the $\left(\mathrm{N}_{1}\right)_{60}$ is determined from site-specific correlations with the tip resistance $\left(\mathrm{q}_{\mathrm{t}}\right)$, sleeve friction $\left(\mathrm{f}_{\mathrm{s}}\right)$ and pore pressure $(\mathrm{u})$ results from seismic and nonseismic piezocone penetrometer test soundings (SCPTU and CPTU) (see Sections 3.4 and 3.5) as well as SPTs (see Section 3.5). The seismically induced CSRs were determined from convolution analysis using SRS soil profiles from WSRC (1997) (see Section 3.6).

The probabilities discussed above combine to form the following liquefaction hazard formulation (WSRC, 1995):

$$
P[L]=\sum_{i} \sum_{j} \sum_{k} \sum_{l} P\left[L \mid C S R N_{k}\left(\bar{v}_{i}, m_{j}\right),\left(\left(N_{1}\right)_{60}\right)_{l}\right] * P\left[v=\bar{v}_{i}, m_{j}\right] *\left[W_{C S R N}\right]_{k}^{*} *\left[W_{N 160}\right]_{l}
$$

Term (1) is computed directly from the results of Liao et al., (1988). Term (2) is derived from the hard-rock PSHA by computing differences of the PSHA disaggregation matrices at each level of motion $v_{i}$ corresponding to magnitude $\mathrm{m}_{\mathrm{j}}$. Terms (3) and (4) are weights dependent on the distributions of cyclic stress ratio and $\left(\mathrm{N}_{1}\right)_{60}$.

\subsection{SRS Hard-Rock PSHAs for Liquefaction Analysis}

Three hard-rock PSHAs were used to evaluate the POL in this study. The EPRI (NEI, 1994), LLNL (Bernreuter, 1997) and the USGS (Frankel, 1999) PSHAs were used in the liquefaction assessments. Hazard curves for oscillator frequencies of $2.5 \mathrm{~Hz}$ are most appropriate for the peak 
cyclic stresses that are controlled in the 1-3 Hz frequency range for deep stiff soils (WSRC, 1995). These PSHAs and their application to the SRS are discussed in greater detail in WSRC (1997) and WSRC (1999). Computation of the CSRN uses the site-wide SRS amplification functions (WSRC, 1997) for the oscillator frequency of $2.5 \mathrm{~Hz}$.

\subsection{PDCF Site Geology}

The existing subsurface database available for F-Area (WSRC, 1996; 2001d) and the PDCF site (LawGibb, 2001) are used to examine the lithology and geology and to layer the subsurface for the PDCF site. As discovered in H-Area, a single laterally continuous weak layer is not distinguishable across F-Area near the PDCF site. Similarly, common markers such as the Tan Clay Unit are identified at many of the CPT sounding and SPT boring locations, and it was possible to layer the PDCF site by geologic formation as well as engineering layers (i.e., subsets of the geologic formations). For this effort, the Tobacco Road, Dry Branch, and Santee Formations were identified as well as the TR1A, TR2A, TR2B, TR3/4, DB1/DB3, DB4/5, ST1, ST2, GC, CG engineering layers (LawGibb, 2001; WSRC, 2001e).

\subsection{Determination of Critical Layer for Liquefaction}

Both CPTU estimated $\left(\mathrm{N}_{1}\right)_{60}$ and fines content (soil finer than the \#200 sieve) were used to determine layers most susceptible to liquefaction. The $\left(\mathrm{N}_{1}\right)_{60}$ was estimated using relationships developed specifically for SRS soils. $\mathrm{N}_{60}$ was computed using Equations 2 and 3. These equations were developed by correlating SPT results with nearby CPTU results (WSRC, 2000c).

$$
\begin{gathered}
\mathrm{N}_{60}=\frac{q_{c}}{8.85-1.85 I_{c}} \\
\mathrm{I}_{\mathrm{c}}=\sqrt{\left(3.25-\log \left[Q_{t}\left(1-B_{q}\right)\right]\right)^{2}+(1.5(1+\log F r))^{2.25}}
\end{gathered}
$$

Where: $\mathrm{Q}_{\mathrm{t}}$ is normalized tip resistance $\mathrm{Q}_{\mathrm{t}}=\left(\mathrm{q}_{\mathrm{t}}-\sigma_{\mathrm{v}}\right) / \sigma_{\mathrm{v}}$

$\mathrm{B}_{\mathrm{q}}$ is pore pressure ratio $\mathrm{B}_{\mathrm{q}}=\left(\mathrm{u}-\mathrm{u}_{\mathrm{o}}\right) /\left(\mathrm{q}_{\mathrm{t}}-\sigma_{\mathrm{v}}\right)$

$\mathrm{Fr}$ is stress normalized friction ratio $\mathrm{Fr}=\left[\left(\mathrm{f}_{\mathrm{s}} / \mathrm{q}_{\mathrm{t}}-\sigma_{\mathrm{v}}\right) \times 100\right]$

$\mathrm{q}_{\mathrm{c}}$ is uncorrected CPTU tip stress

$\mathrm{q}_{\mathrm{t}}$ is CPTU tip stress corrected for unequal area effects

$\mathrm{f}_{\mathrm{s}}$ is CPTU sleeve friction

The $\mathrm{N}_{60}$ values were normalized to $\left(\mathrm{N}_{1}\right)_{60}$ values using Equation 4 (Liao and Whitman, 1986).

$$
\left(\mathrm{N}_{1}\right)_{60}=\mathrm{N}_{60} \times\left[1 /\left(\sigma_{\mathrm{v}}{ }^{\prime}\right)\right]^{0.5}
$$

In order to account for the increase in liquefaction resistance due to increase in fines content it is also necessary to determine fines content for a layer being evaluated. Fines content was also estimated using CPTU data as follows:

$$
\begin{gathered}
\text { Fines }=29.47\left(\mathrm{I}_{\mathrm{fc}}\right)^{1.21}-0.09 \\
\mathrm{I}_{\mathrm{fc}}=\left[\left(1.60-\log \mathrm{Q}_{\mathrm{t}}\right)^{2}+(\log \mathrm{Fr}+0.41)^{2}\right]^{0.5}
\end{gathered}
$$


Where $Q_{t}$ and Fr are the same as those provided for Equation 3. Equations 5 and 6 were developed by correlating laboratory determined fines content from borings with nearby CPTU results (WSRC, 2001f).

The estimated $\left(\mathrm{N}_{1}\right)_{60}$ and fines content were used to determine what layer might be most susceptible to liquefaction. At the PDCF site, the Tobacco Road Formation is above the water table. Only the TR2B, TR3/4 and DB1/DB3 layers within the Dry Branch Formation were evaluated. Data collected at greater depths (i.e., within the Santee Formation or deeper) and above the water table were not considered. Of these three layers the TR3/4 has the lowest average $\left(\mathrm{N}_{1}\right)_{60}$, however, the TR3/4 layer (also known as the Tan Clay Unit) has an average fines content of about 37 percent. Thus, the critical layer selected to represent PDCF was the DB1/DB3 layer having an average fines content of about 12 percent. Table 1 summarizes average $\left(\mathrm{N}_{1}\right)_{60}$ and fines content for the TR2B, TR3/4 and DB1/DB3 layers. On average, the F-Area saturated DB1/DB3 layer was about 24 feet thick having an average elevation between approximately $180 \mathrm{ft} \mathrm{msl}$ and $204 \mathrm{ft} \mathrm{msl}$. At the PDCF site the saturated DB1/DB3 layer is about 26 feet thick having an average elevation between approximately $212 \mathrm{ft} \mathrm{msl}$ and $186 \mathrm{ft} \mathrm{msl}$ (see Figure 2).

Table 1. Average $\left(\mathbf{N}_{1}\right)_{60}$ Values and Fines Content for Saturated Portions of the TR2B, TR3/4, and DB1/DB3 Engineering Layers

\begin{tabular}{|c|c|c|c|c|}
\hline \multirow{2}{*}{ Layer } & \multicolumn{2}{|c|}{ PDCF Site } & \multicolumn{2}{c|}{ F-Area } \\
\cline { 2 - 5 } & $\begin{array}{c}\text { Mean CPTU } \\
\text { estimated }\left(\mathbf{N}_{\mathbf{1}}\right)_{60}\end{array}$ & $\begin{array}{c}\text { Mean Fines } \\
\text { Content }\end{array}$ & $\begin{array}{c}\text { Mean CPTU } \\
\text { estimated }\left(\mathbf{N}_{1}\right)_{60}\end{array}$ & $\begin{array}{c}\text { Mean Fines } \\
\text { Content }\end{array}$ \\
\hline TR2B & 19.4 & 9.2 & 18.2 & 11.2 \\
\hline TR3/4 & 8.6 & 36.6 & 8.0 & 21.7 \\
\hline DB1/DB3 & 17.7 & 11.6 & 15.3 & 12.5 \\
\hline
\end{tabular}

\subsection{Determination of Soil Capacity $\left(\mathrm{N}_{1}\right)_{60}$}

In order to utilize published probabilistic liquefaction curves (Liao et al., 1988) the CPTU results were converted to equivalent $\left(\mathrm{N}_{1}\right)_{60}$ values using equations 2,3 and 4 in Section 3.4. The $\left(\mathrm{N}_{1}\right)_{60}$ mean and standard deviation were determined for the critical layer along with histograms of the data and log transformed data. The PDCF site histograms of CPTU estimated $\left(\mathrm{N}_{1}\right)_{60}$ and CPTU estimated $\ln \left(\mathrm{N}_{1}\right)_{60}$ are shown in Figures 3 and 4.

Histograms of SPT determined $\left(\mathrm{N}_{1}\right)_{60}$ and $\ln \left(\mathrm{N}_{1}\right)_{60}$ values for the DB1/DB3 layer at the PDCF site are shown in Figures 5 and 6. The PDCF CPTU estimated values in Figures 3 and 4 are comparable with the SPT determined values shown in Figures 5 and 6 giving further confidence in the equations used to determine $\left(\mathrm{N}_{1}\right)_{60}$ using CPTU measurements.

The conditional probability of liquefaction model developed by Liao et al. (1988) was based on data entirely from the Holocene (recent) period. The soils in question at the SRS are of the Miocene period and as such, have significantly higher cyclic strength than Holocene soils. Thus, modifications to the Liao model were required. Specifically, corrections are required to account for aging, overconsolidation and sample disturbance. Each is discussed below. 


\subsubsection{Aging}

Aging has been addressed at the SRS through extensive laboratory testing of recovered samples from the Tobacco Road, Dry Branch and Santee Formations. The results show that the soils at the SRS have significantly higher cyclic shear strengths than similar soils of the Holocene period. The results have been used to develop SRS site-specific curves accounting for aging of the soils at the SRS. The resulting average increase in strength for the SRS soils over the Holocene soils is 1.35 (WSRC, 1995).

\subsubsection{Overconsolidation}

The site-specific cyclic shear strength curves are based on an overconsolidation ratio (OCR) estimate of 2. A best estimate of the OCR for the Dry Branch Formation in F-Area ranges between approximately 1 and 2. For this evaluation an OCR of 2 has been adopted. Thus, no correction is made for OCR for the critical layer in F-Area or PDCF.

\subsubsection{Sample Disturbance}

The SRS curves do not account for potential loss of strength due to sample disturbance. It is well known that even the most carefully planned and implemented sampling and testing program will result in disturbance to the recovered samples. It is also well known that laboratory derived strengths are less than in-situ strength due to sample handling and disturbance. For site-specific deterministic liquefaction potential determinations, these effects are conservatively ignored. For this study however, the affects are considered in an effort to obtain a "best estimate" result.

Strength losses of up to $30 \%$ can be realized due to sample disturbance (Singh, et al., 1979). Thus, to account for these potential losses, a correction factor of 1.3 is recommended (WSRC, 1995).

Combining the factors from aging, overconsolidation and sample disturbance results in an overall factor of 1.75 , i.e., $1.35 \times 1.0 \times 1.3=1.75$. This factor was applied to the Liao et al. (1988) model for the probabilistic assessment.

\subsection{Seismic Demand (CSRN)}

Earthquake demand or Cyclic Stress Ratio (CSR) is defined as effective shear stress $\left(\tau_{\text {ave }}\right)$ divided by effective overburden pressure $\left(\sigma_{\mathrm{v}}^{\prime}\right)$. A soil unit weight of $120 \mathrm{pcf}$ was used to compute $\sigma_{\mathrm{v}}$ with an average water table depth of 65 feet. This is conservative, as the water table on average is 70 to 75 feet deep in the PDCF site area. A shallow water table results in lower $\sigma_{\mathrm{v}}^{\prime}$ and therefore a greater CSR.

The CSRs for the PDCF site were computed using previously developed bedrock motions and soil models representative of the General Separations Area (GSA) at SRS (WSRC, 1997). The PDCF site is consistent with the general site model (WSRC, 1997; LawGibb, 2001). The bedrock control motions cover a range of earthquake magnitudes and peak ground accelerations. The 
control motions are convolved through the soil to compute the average distribution of CSR for each layer in the soil model (WSRC, 1997). As the critical layer is thicker (about $26 \mathrm{ft}$ thick) than the convolution model layers (each about $10 \mathrm{ft}$ thick), the CSR for the critical layer is determined by averaging the appropriate CSRs over the critical layer depth range. The control motion spectra are computed for a large range of hypothetical earthquakes so tables of CSR distributions can be interpolated. Thus, by differencing the PSHA disaggregation, the probability of occurrence of a specific level of bedrock motion is obtained corresponding to a range of earthquake magnitude and distance. The corresponding CSR distribution is then determined from interpolated tables.

Convolution analysis used to compute CSRs is consistent with the 1997 SRS seismic design spectra (WSRC, 1997). Bedrock spectra and CSRs were computed for three magnitude levels and eight levels of peak ground acceleration (PGA) covering the range $0.05-0.75 \mathrm{~g}$. Because the site-specific CSRs cover a limited range of bedrock motions, the CSR distributions were extrapolated to lower and higher control motions. The lower control motion extrapolations (for PGA < 0.05) are not critical to the final result. The higher control motion extrapolations (for PGA $>0.75 \mathrm{~g}$ ) could impact the final results by underestimating or overestimating the CSR demand. For the EPRI, LLNL, and USGS PSHAs, only about $25 \%$ of the POL contributions are made from control motion ranges that use extrapolated ranges of CSR.

Before the CSR distributions can be used in conjunction with the Liao et al. (1988) model they must be normalized for earthquake magnitude. Table 2 presents the magnitude scaling factors (MSFs) used to normalize the CSRs to CSRNs. Figure 7 presents several MSFs that have been proposed by various investigators (NCEER, 1997). Also presented in Figure 7 is the range of MSFs recommended from the NCEER workshop. The Arango MSFs (denoted in Figure 7 by an open diamond) fall in the middle of the recommended range for most of the magnitudes and overall the Arango MSFs approximate a "best estimate". The Arango MSFs are used except for Mw of 5.5 where a MSF of 2.5 more closely fits the middle of the NCEER recommended range.

Table 2. Magnitude Scaling Factors

\begin{tabular}{|c|c|}
\hline $\begin{array}{c}\text { Earthquake } \\
\text { Magnitude }\end{array}$ & $\begin{array}{c}\text { Magnitude } \\
\text { Scaling } \\
\text { Factor }\end{array}$ \\
\hline 8.25 & 0.63 \\
\hline 8 & 0.75 \\
\hline 7.5 & 1.0 \\
\hline 7 & 1.25 \\
\hline 6 & 2.0 \\
\hline 5.5 & $2.5^{+}$ \\
\hline${ }^{+}$All MSF values approximate middle of \\
NCEER (1997) recommendation. The \\
MSF values are (Arango, 1994; 1996) \\
except Mw 5.5.
\end{tabular}




\subsection{RESULTS}

\subsection{Evaluation of PDCF Probability of Liquefaction}

For the PDCF POL assessment, the seismic demand, soil capacity, and correction factors were the same as those used in the F-Area POL assessment. Table 3 below summarizes the PDCF POL runs and shows the results.

Table 3. Summary of PDCF POL Results

\begin{tabular}{|l|c|c|c|c|c|c|c|}
\hline PSHA & $\begin{array}{c}\text { Seismic } \\
\text { Demand } \\
\text { CSR }\end{array}$ & $\begin{array}{c}\text { Soil } \\
\text { Capacity } \\
\left(\mathrm{N}_{1}\right)_{60}\end{array}$ & $\begin{array}{c}\text { Soil } \\
\text { Strength } \\
\text { Factor }\end{array}$ & Layer & $\begin{array}{c}\text { Magnitude } \\
\text { Fcaling } \\
\text { Factor }\end{array}$ & $\begin{array}{c}\text { P[L] } \\
\text { Model }\end{array}$ & $\begin{array}{c}\text { POL } \\
\text { /yr }\end{array}$ \\
\hline EPRI & SRS 1997 & CPTU & 1.75 & DB1/DB3 & NCEER & Undiff. & $1.06 \times 10^{-6}$ \\
\hline LLNL & SRS 1997 & CPTU & 1.75 & DB1/DB3 & NCEER & Undiff. & $8.32 \times 10^{-6}$ \\
\hline USGS & SRS 1997 & CPTU & 1.75 & DB1/DB3 & NCEER & Undiff. & $2.17 \times 10^{-5}$ \\
\hline EPRI & SRS 1997 & SPT & 1.75 & DB1/DB3 & NCEER & Undiff. & $1.76 \times 10^{-6}$ \\
\hline LLNL & SRS 1997 & SPT & 1.75 & DB1/DB3 & NCEER & Undiff. & $1.39 \times 10^{-5}$ \\
\hline USGS & SRS 1997 & SPT & 1.75 & DB1/DB3 & NCEER & Undiff. & $3.59 \times 10^{-5}$ \\
\hline
\end{tabular}

POL is computed using the Liao et al. (1988) probability model for undifferentiated sand. During the H-Area POL assessment (WSRC, 2000a) it was noted that the computed POL increased going from clean sand to silty sands. This result was contrary to engineering experience as increased fines content generally decreases the probability of liquefaction. However, according to the Liao et al. (1988) contours of equal probability of liquefaction, lower CSRs $(<0.1)$ are associated with higher POL for silty sands as compared to clean sands (see Figures 1a and 1b). Because a majority of the POL contributions for PDCF come from relatively low induced CSRs, the total POL computed for silty sands is greater than that computed for clean sands. This result decreases our confidence in the partitioning of silty and clean sands. Therefore, the undifferentiated model was selected. Using equal weighting of the six PSHAs, the mean annual POL is $1.38 \times 10^{-5}$ (geometric mean of $7.43 \times 10^{-6}$ ).

The PDCF POL disaggregation by earthquake magnitude is given in Table 4 below. The POL by magnitude $(\mathrm{Mw})$ is given as a percentage of the total. The indicated magnitude is the centroid of the magnitude bin. 
Table 4. PDCF POL Magnitude Disaggregation

\begin{tabular}{|c|c|c|c|c|c|c|c|c|}
\hline \multicolumn{3}{|c|}{ EPRI } & \multicolumn{3}{c|}{ LLNL } & \multicolumn{3}{c|}{ USGS } \\
\hline $\mathrm{Mw}$ & $\begin{array}{c}\text { POL \% } \\
(\mathrm{CPT})\end{array}$ & $\begin{array}{c}\text { POL \% } \\
(\mathrm{SPT})\end{array}$ & $\mathrm{Mw}$ & $\begin{array}{c}\text { POL \% } \\
(\mathrm{CPT})\end{array}$ & $\begin{array}{c}\text { POL \% } \\
(\mathrm{SPT})\end{array}$ & $\mathrm{Mw}$ & $\begin{array}{c}\text { POL \% } \\
\text { (CPT) }\end{array}$ & $\begin{array}{c}\text { POL \% } \\
(\mathrm{SPT})\end{array}$ \\
\hline 4.75 & 0.0 & 0.1 & 5.25 & 1.0 & 1.4 & 4.75 & 0.0 & 0.0 \\
\hline 5.25 & 0.7 & 1.0 & 5.75 & 3.9 & 5.0 & 5.25 & 0.1 & 0.1 \\
\hline 5.9 & 10.6 & 13.8 & 6.25 & 12.1 & 14.0 & 5.75 & 0.3 & 0.5 \\
\hline 6.7 & 42.4 & 46.5 & 6.75 & 38.4 & 40.0 & 6.25 & 1.6 & 1.9 \\
\hline 7.8 & 46.2 & 38.6 & 7.5 & 44.6 & 39.7 & 6.75 & 2.1 & 2.1 \\
\hline & & & & & & 7.5 & 95.8 & 95.4 \\
\hline
\end{tabular}

Note: Magnitude disaggregation is for "undifferentiated" Liao et al. (1988) model. The percentages do not add to $100 \%$ because of round-off.

Note the substantial difference in the USGS magnitude composition as compared to EPRI and LLNL. The large contribution to the USGS Mw 7.5 magnitude bin is the Charleston characteristic earthquake source (Mw 7.3). The EPRI and LLNL PSHAs used a distribution of earthquake magnitudes to describe the Charleston seismic source. We believe that a preferred hazard model would contain a weighted combination of magnitude distributions.

The cumulative contribution to the POL by loop index number (product of terms (1), (2), (3), and (4) of Equation 1) is illustrated in Figure 8 using the EPRI PSHA. This figure shows that a proper range in bedrock motions were considered for the problem as the distribution is complete in its symmetry. The cumulative POL (equation 1) should have small contributions at low control motion because although the probability of occurrence of motion is high, the liquefaction potential is very low. The cumulative POL should have small contributions at high control motions because although the liquefaction potential may be relatively high, the probability of ground motion occurrence is very low. Thus, the contributions to the POL should be small at the high and low ends of control motion used in the analysis, otherwise, the POL could be significantly underestimated. Figures 9 and 10 illustrate the cumulative POL by loop index number for the LLNL and USGS PSHAs. The LLNL and USGS cumulative POL plots also suggest that a complete range of bedrock motion were considered for the problem. 


\subsection{CONCLUSIONS}

A PDCF POL assessment was made using soil seismic demand consistent with the "SRS Seismic Response Analysis and Design Basis Guidelines" (WSRC, 1997). Preliminary confirmation of the applicability of the site-wide soil response database to the PDCF site was established using the available PDCF velocity profiles (LawGibb, 2001). The soil layers most susceptible to liquefy, the critical layers, and their capacity were established using site-specific CPTU tip resistance and their correlation to SPT $\left(\mathrm{N}_{1}\right)_{60}$. Using the Liao et al. (1988) correlation between soil seismic demand and capacity, the POL is computed in a straightforward manner following adjustments for soil sample disturbance, OCR and age. The POL assessments were made using three hard-rock PSHAs: EPRI, LLNL and USGS. Results are documented in calculation K-CLC-F-00058 (WSRC, 2001g) as required by the WSRC E7 Conduct of Engineering and Technical Support Manual.

Based on the methodology presented herein, the mean annual POL for PDCF is about $1.4 \times 10^{-5}$ (geometric mean about $7.4 \times 10^{-6}$ ). This is compared to the mean annual POL for F-Area of about

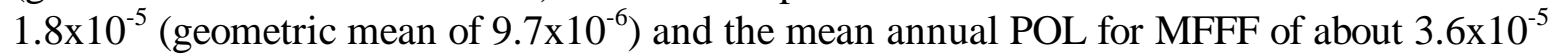
(geometric mean of $1.9 \times 10^{-5}$ ).

The mean POL for the PDCF is about the same as the mean F-Area POL, which are both less than for H-Area (mean annual probability of $4.3 \times 10^{-5}$ ). 


\subsection{REFERENCES}

Arango, I., 1994. Methodology for Liquefaction Potential Evaluation of Sites East of the Rockies, Bechtel Corporation, Technical Grant, June 1994.

Arango, I., 1996. Magnitude Scaling Factors for Soil Liquefaction Evaluations, Journal of Geotechnical Engineering, ASCE, Vol. 122, No. 11, pp. 929-936, November 1996.

Bernreuter, Don L., 1997. Letter from Don Bernreuter of Lawrence Livermore National Laboratory to Jeff Kimball of U. S. Dept. of Energy, Re: transmittal of rock hazard results for Savannah River Site, May 15, 1997.

Frankel, A., 1999. Letter from A. Frankel of USGS to R. C. Lee, Re: Results of USGS calculation of SRS PSHA, March 1, 1999.

LawGibb, 2001. PDCF Geotechnical Report (Draft), June 2001.

Liao, Samson S. C., and Robert V. Whitman, 1986. Overburden Correction Factors for SPT in Sand, Journal of Geotechnical Engineering, ASCE, Vol. 112, No. 3, pp. 373-377.

Liao, Samson S. C., Veneziano, D., and Robert V. Whitman, 1988. Regression Models for Evaluating Liquefaction Probability, Journal of Geotechnical Engineering, ASCE, Vol. 114, No. 4, pp. 389-411.

NCEER, 1997. Proceedings of the NCEER Workshop on Evaluation of Liquefaction Resistance of Soils, National Center for Earthquake Engineering Research, Technical Report No.

NCEER-97-0022, State University of New York at Buffalo, New York, December 31, 1997.

NEI, 1994. Seismic Siting Decision Process, Nuclear Energy Institute, Washington, D. C., May 24, 1994.

Singh, S., Seed, H. B., and C. K. Chan, 1979. Undisturbed Sampling and Cyclic Load Testing of Sands, Report No. UCB/EERC-79/33, University of California at Berkeley, Berkeley, California.

WSRC, 1995. In Tank Precipitation Facility (ITP) and H-Tank Farm (HTF) Geotechnical Report, WSRC-TR-95-0057, Rev. 0, September 1995.

WSRC, 1996. F-Area Geotechnical Characterization Report, WSRC-TR-96-0069, Rev. 0, September 1996.

WSRC, 1997. SRS Seismic Response Analysis and Design Basis Guidelines, WSRC-TR-97-0085, Rev. 0, March 31, 1997. 
WSRC, 1999. Computation of USGS Soil UHS and Comparison to NEHRP and PC1 Seismic Response Spectra for the SRS, WSRC-TR-99-0271, Rev. 0, September 1999.

WSRC, 2000a. Probability of Liquefaction for H-Area, Savannah River Site, WSRC-TR-2000-00039, Rev. 0, August 31, 2000.

WSRC, 2000c. CPTU (N1) ${ }_{60}$ Determination, K-CLC-G-00067, Rev. 0, August 2000.

WSRC 2001a. Probability of Liquefaction for F-Area and MOX Fuel Fabrication Facility (MFFF) Site, Savannah River Site, WSRC-TR-2001-00043, January 31, 2001.

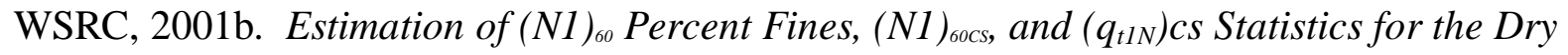
Branch Formation at the PDCF Site Using Piezocone Penetration Test Data, K-CLC-F-00056, Rev. 0, August 2001.

WSRC, 2001c. SPT (N1) $)_{60}$ Statistics for the Saturated TR2B, TR3/TR3, and DB1/DB3 Layers at the PDCF Site, K-CLC-F-00057, Rev. 0, August 2001.

WSRC 2001d. F-Area Northeast Expansion Report (U), K-TRT-F-00001, Rev. 1, January 31, 2001.

WSRC, 2001e. Determination of Stratagraphic Tops for F and H Area Tobacco Road, Dry Branch and Santee Formations, K-CLC-G-00069, Rev. 1, January 2001.

WSRC, 2001f. CPTU Fines Content Determination, K-CLC-G-00065, Rev. 0, August 2001.

WSRC, 2001g. Probability of Liquefaction for Pit Disassembly and Conversion Facility Calculated Using Computer Program LIQHAZ, K-CLC-F-00058, Rev. 0, August 2001. 


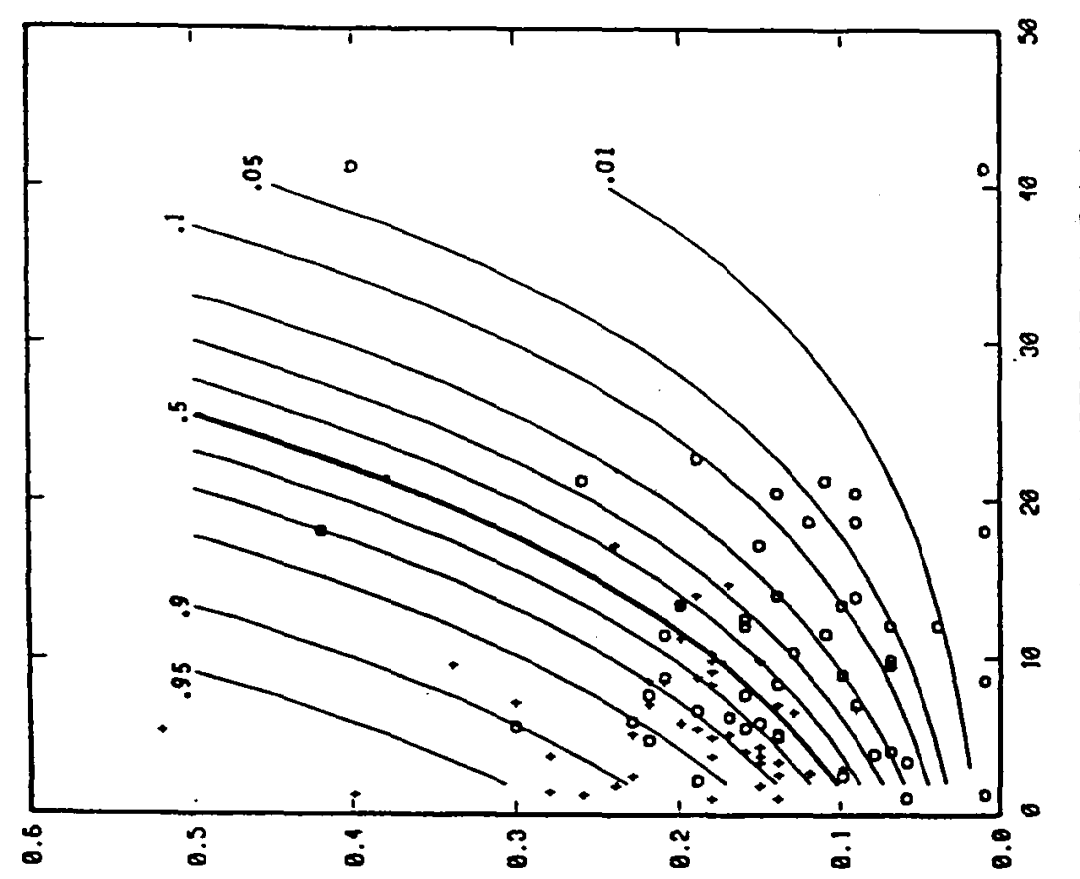

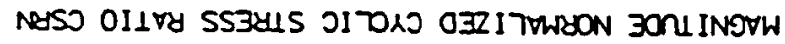
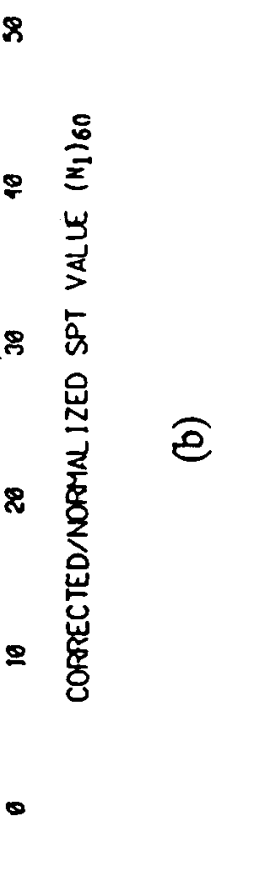

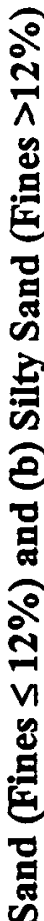

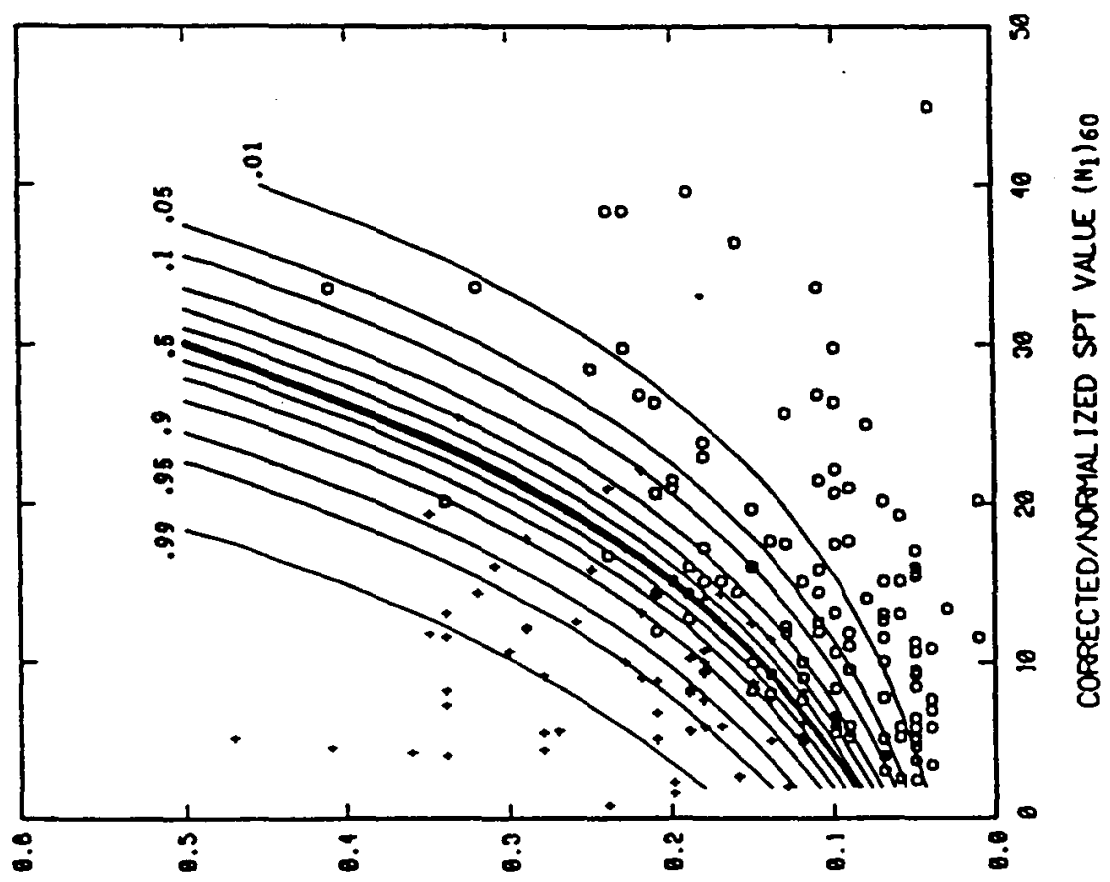

蛋冬

สิ

호웡

옵

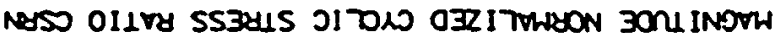


GENERALIZED PROFILE

FOR PDCF SITE

SURFACE

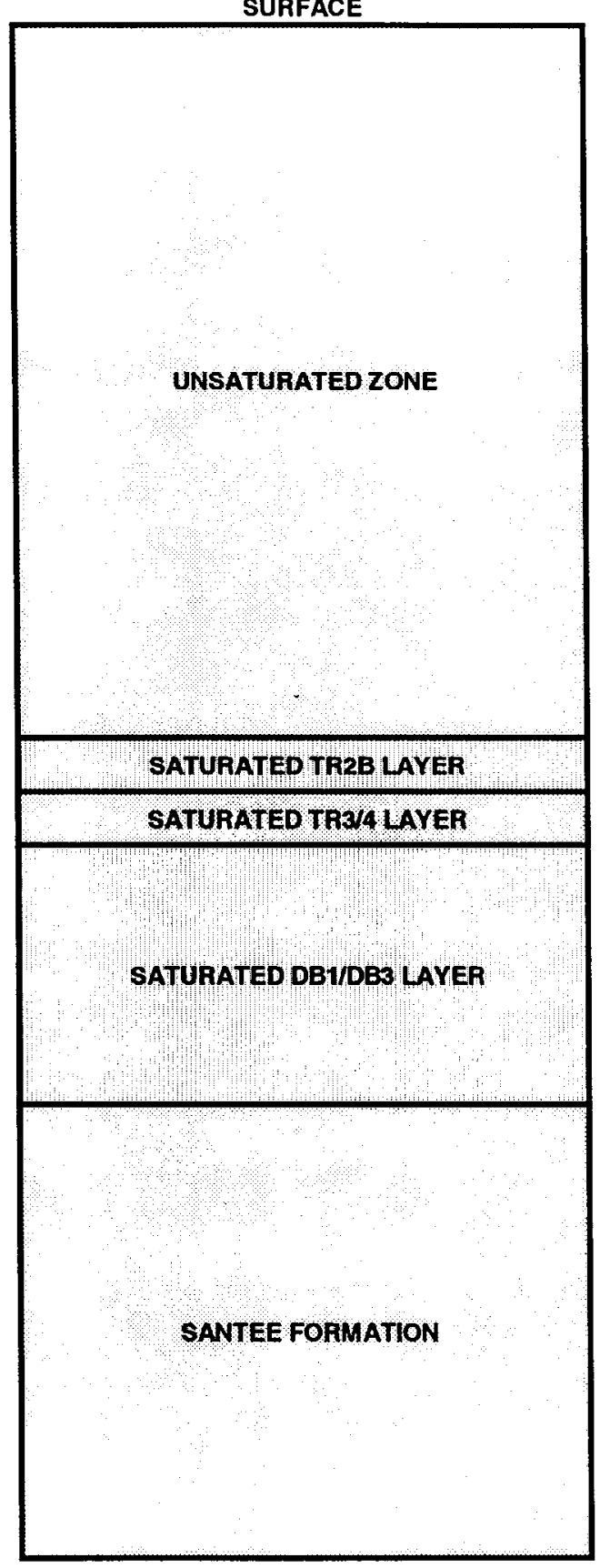

\begin{tabular}{|c|c|c|c|c|}
\hline $\begin{array}{c}\text { Bottom } \\
\text { Elevation } \\
\text { (feet MSL) }\end{array}$ & $\begin{array}{c}\text { CPT } \\
\text { Calculated } \\
\left(\mathrm{N}_{1}\right)_{\infty} \\
\text { (blows per } \mathrm{ft} \text { ) }\end{array}$ & $\begin{array}{c}\text { SPT } \\
\left(\mathrm{N}_{1}\right)_{\infty 0} \\
\text { (blows per ft) }\end{array}$ & $\begin{array}{c}\text { Tip Stress } \\
q_{t} \\
\text { (tsf) }\end{array}$ & $\begin{array}{c}\text { CPT } \\
\text { Estimated } \\
\text { Fines } \\
\text { Content }\end{array}$ \\
\hline
\end{tabular}

$294.5( \pm 11.8)$

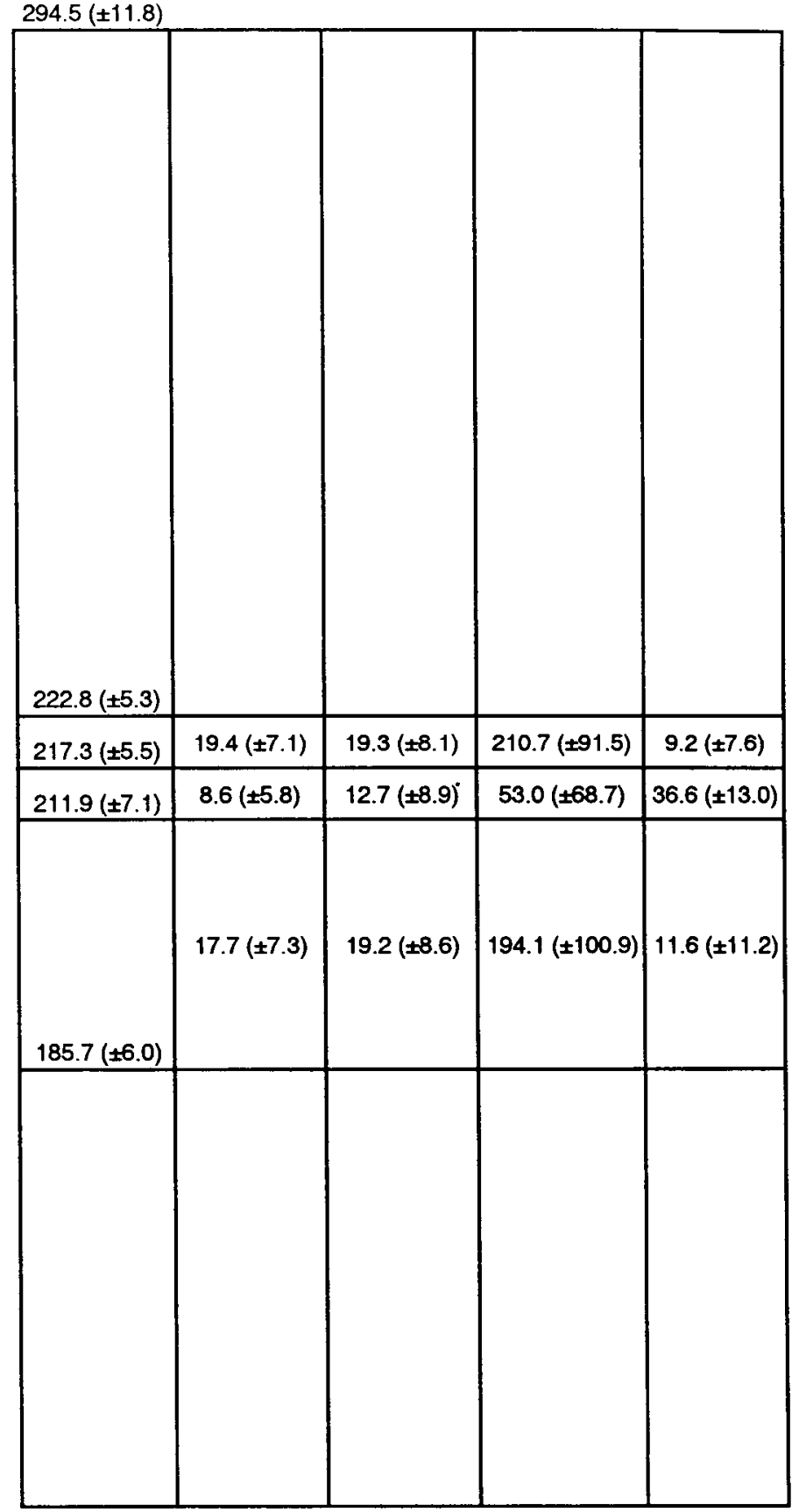

Numbers shown are average values, numbers in parentheses are standard deviations.

Figure 2. Generalized Cross Section for PDCF 


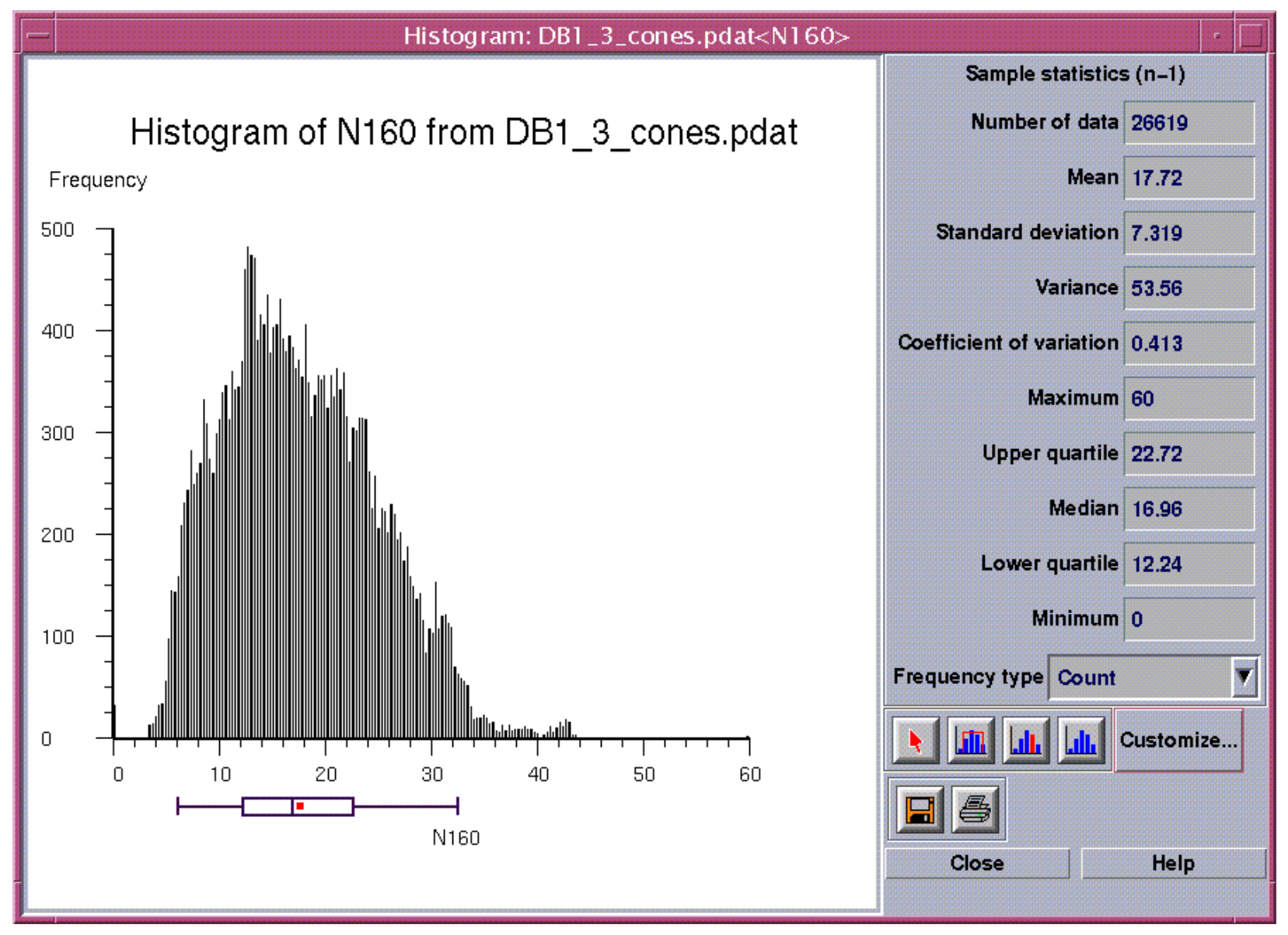

Figure 3. Histogram of CPTU Estimated $\left(\mathrm{N}_{1}\right)_{60}$ Values for the PDCF Saturated DB1/DB3 Layer 


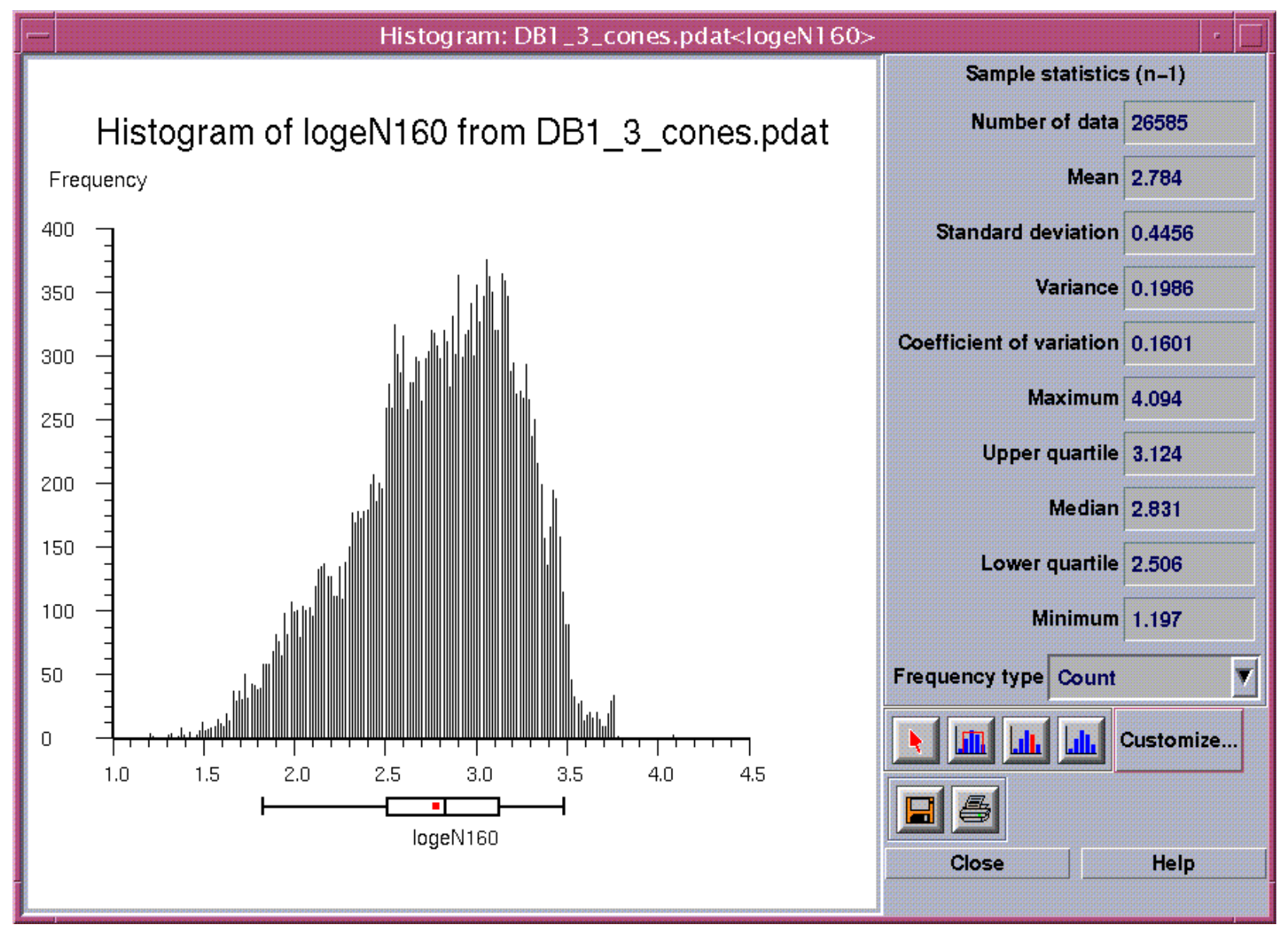

Figure 4. Histogram of CPTU Estimated $\ln \left[\left(\mathbf{N}_{1}\right)_{6_{0}}\right]$ Values for the PDCF Saturated DB1/DB3 Layer 


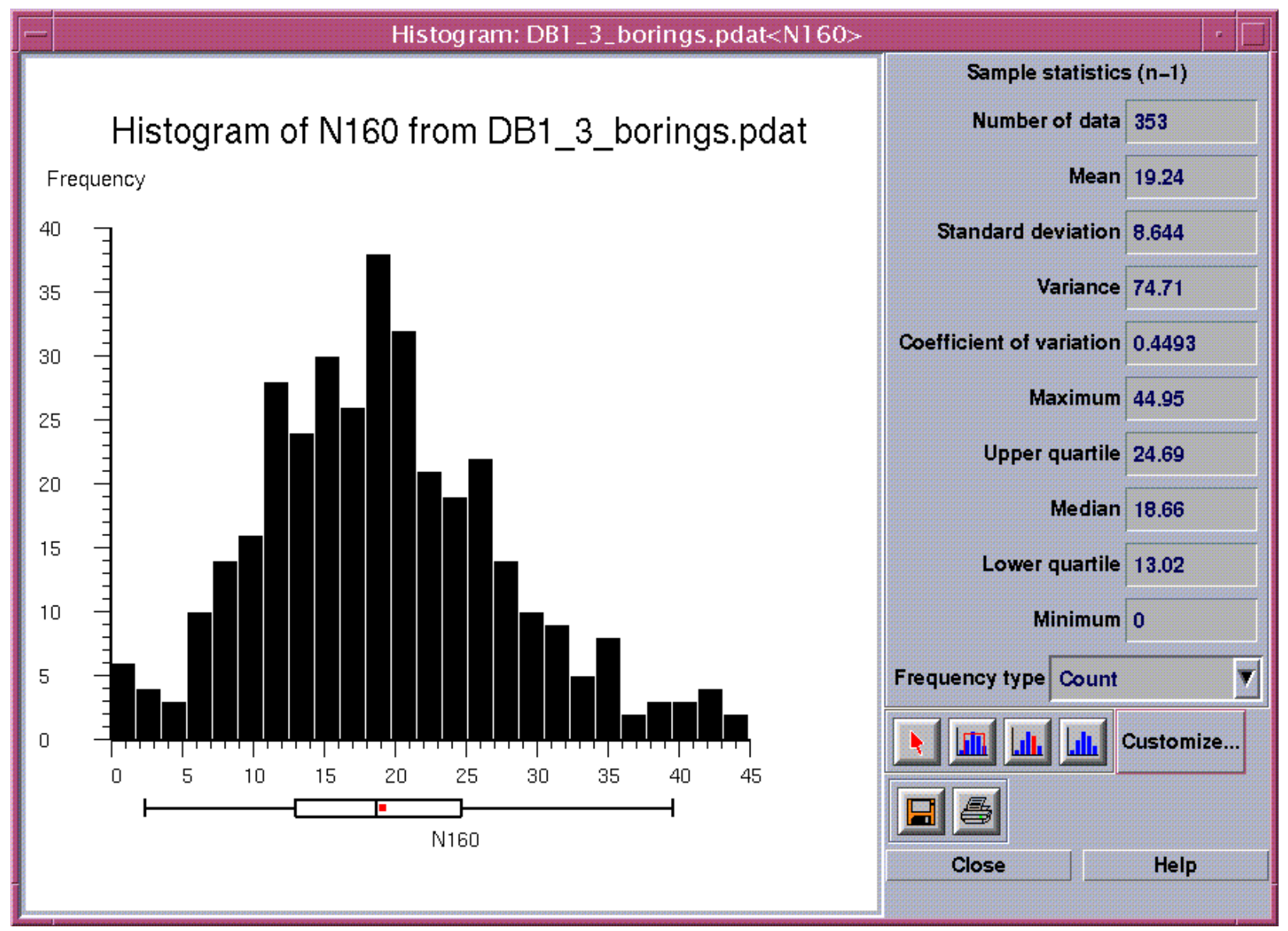

Figure 5. Histogram of SPT Determined $\left(\mathrm{N}_{1}\right)_{60}$ Values for the PDCF Site Saturated DB1/DB3 Layer 


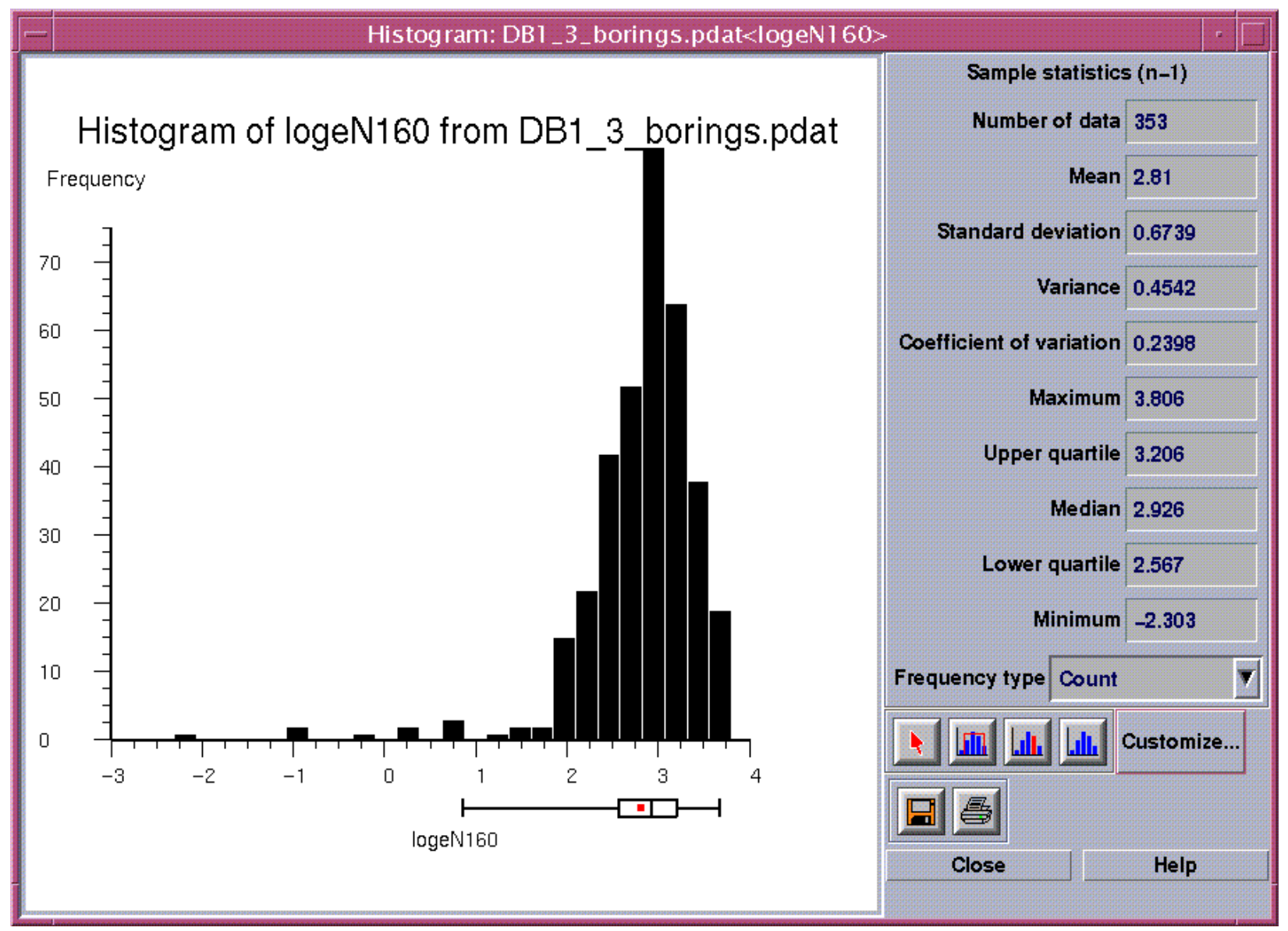

Figure 6. Histogram of SPT Determined $\ln \left[\left(\mathrm{N}_{1}\right)_{60}\right]$ Values for the PDCF Site Saturated DB1/DB3 Layer 


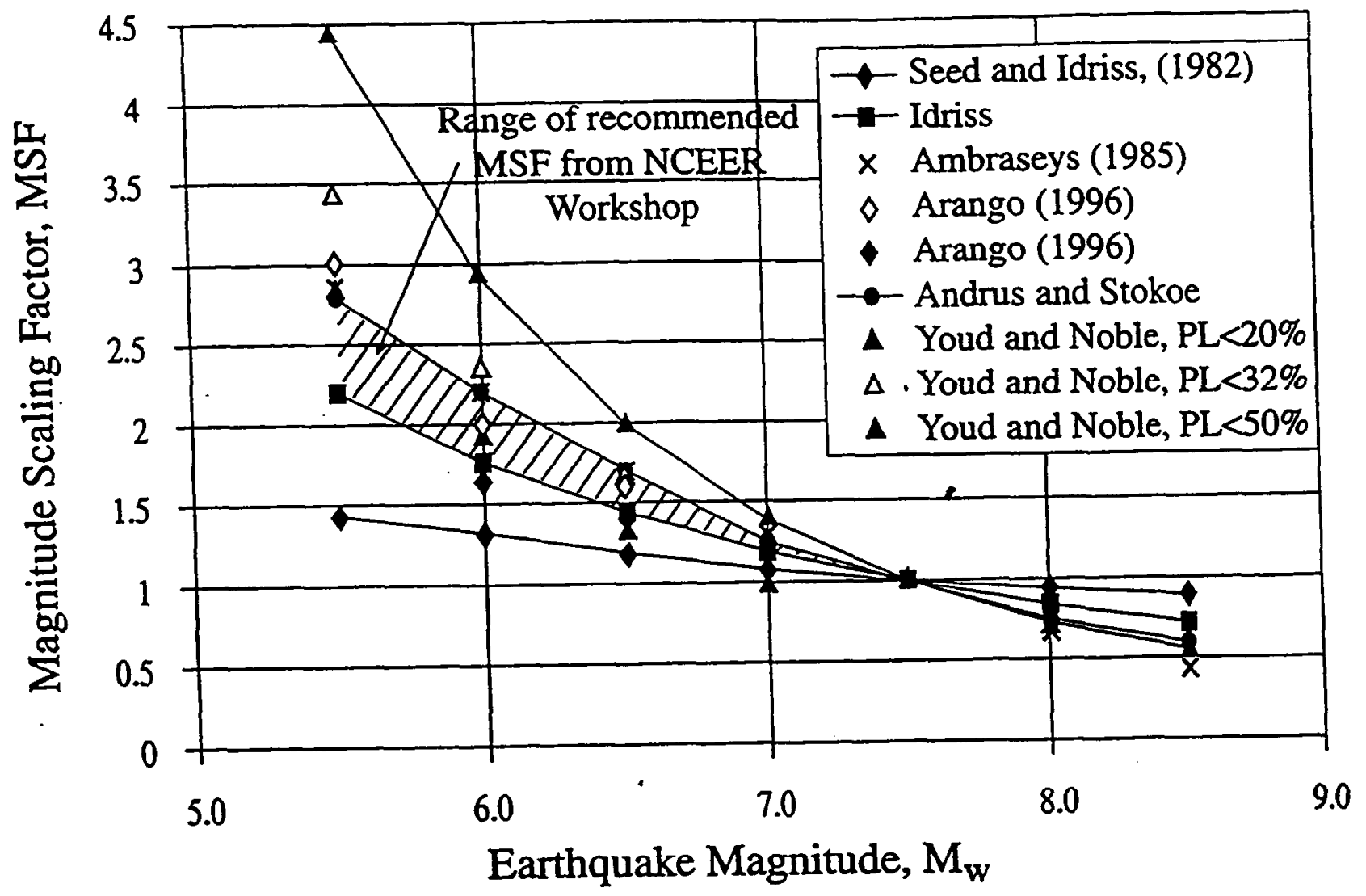

Figure 7. Magnitude Scaling Factors Proposed by Various Investigators (NCEER, 1997) 
EPRI PDCF Site Cumulative POL by Loop

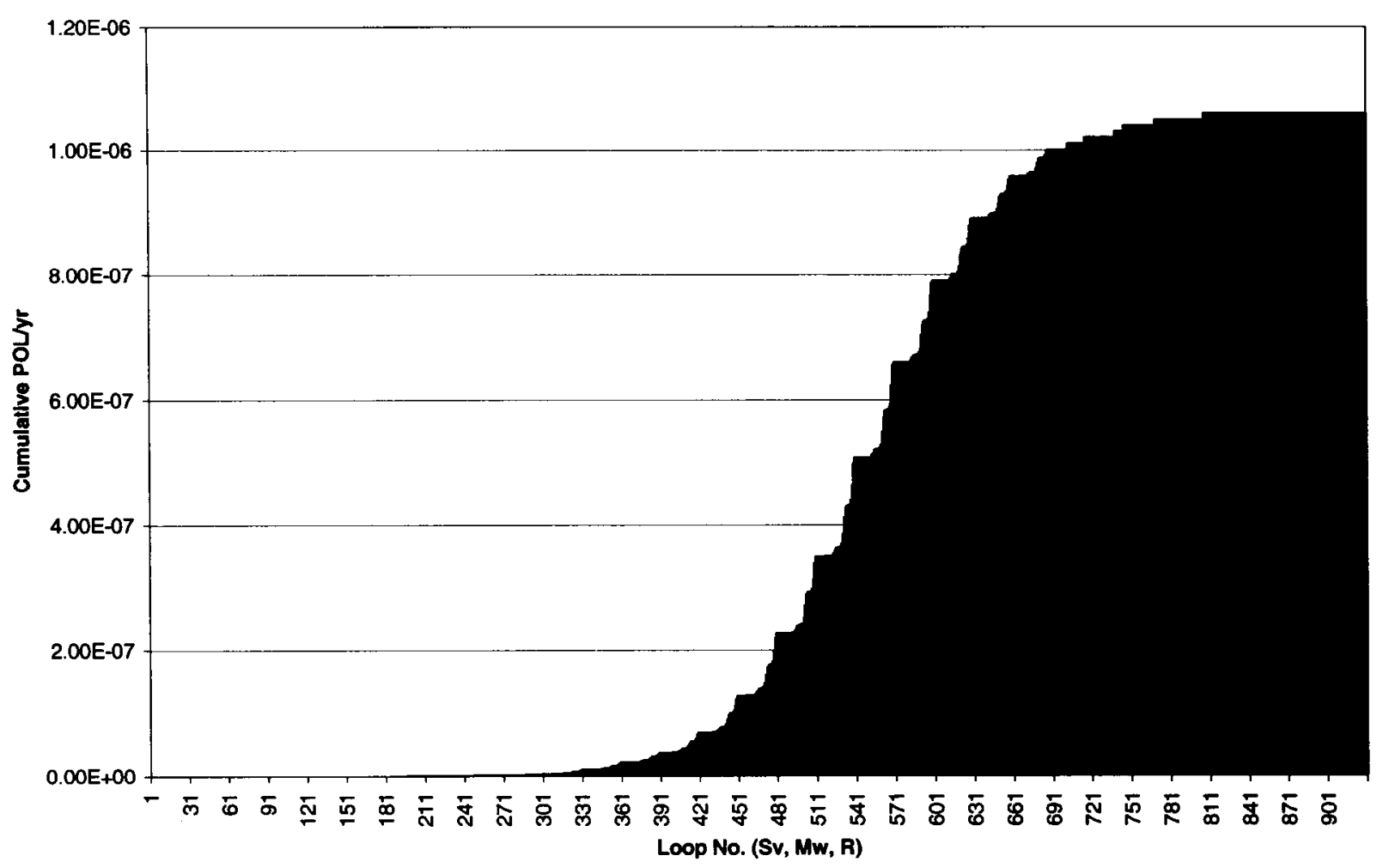

Figure 8. EPRI PDCF Site Cumulative Probability of Liquefaction Summed by Loop 31 increasing $\mathrm{Sv}$ levels at $2.5 \mathrm{hz}, 5$ increasing $\mathrm{Mw}$ bins, and 6 increasing distance bins $\left(\mathbf{N}_{1}\right)_{60}$ Values Calculated Using CPTU Data

(Equation 1, see page 7) 
LLNL PDCF Site Cumulative POL by Loop

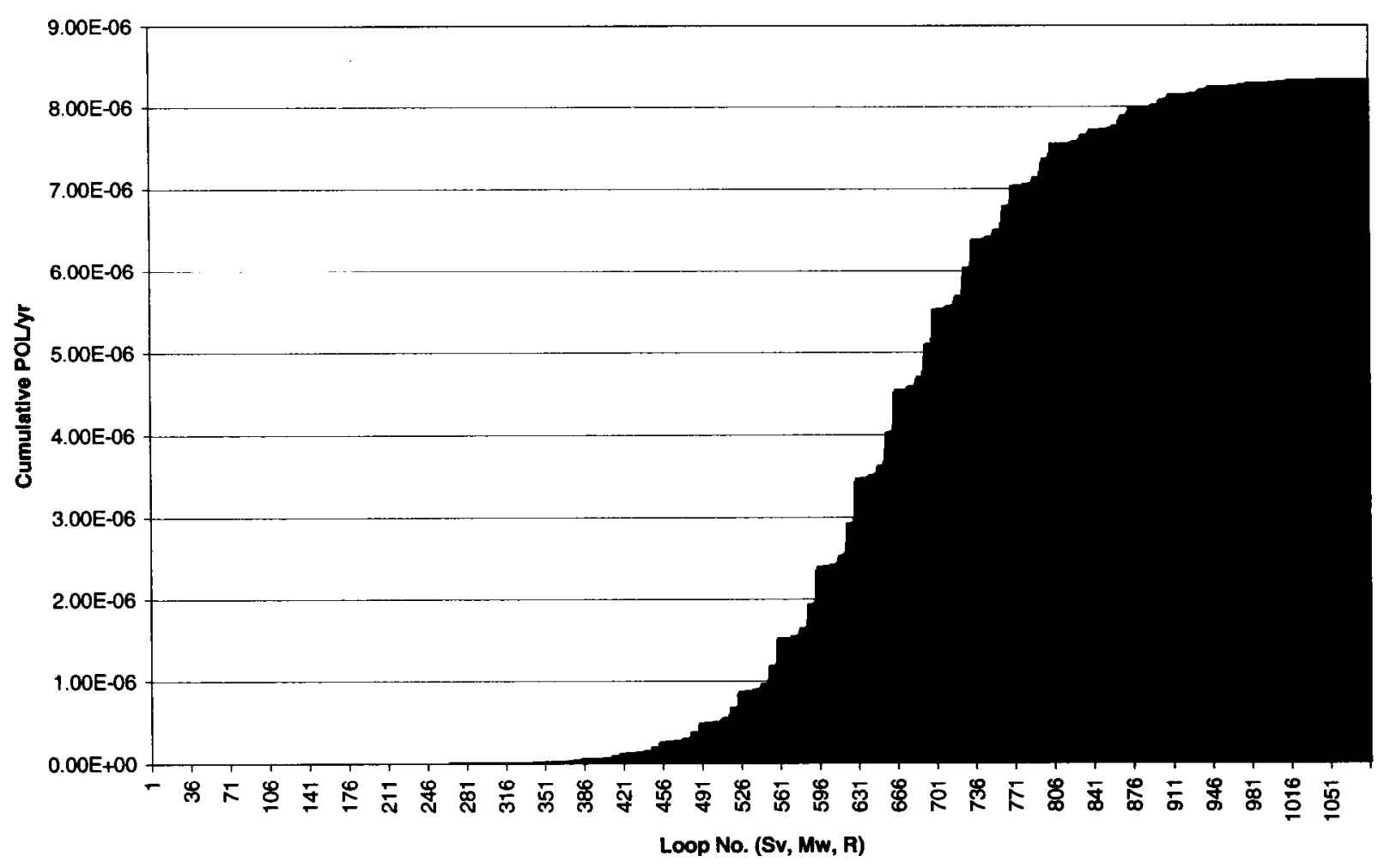

Figure 9. LLNL PDCF Site Cumulative Probability of Liquefaction Summed by Loop 31 increasing $\mathrm{Sv}$ levels at $2.5 \mathrm{hz}, 5$ increasing $\mathrm{Mw}$ bins, and 7 increasing distance bins $\left(\mathrm{N}_{1}\right)_{60}$ Values Calculated Using CPTU Data

(Equation 1, see page 7) 
USGS PDCF Site Cumulative POL by Loop

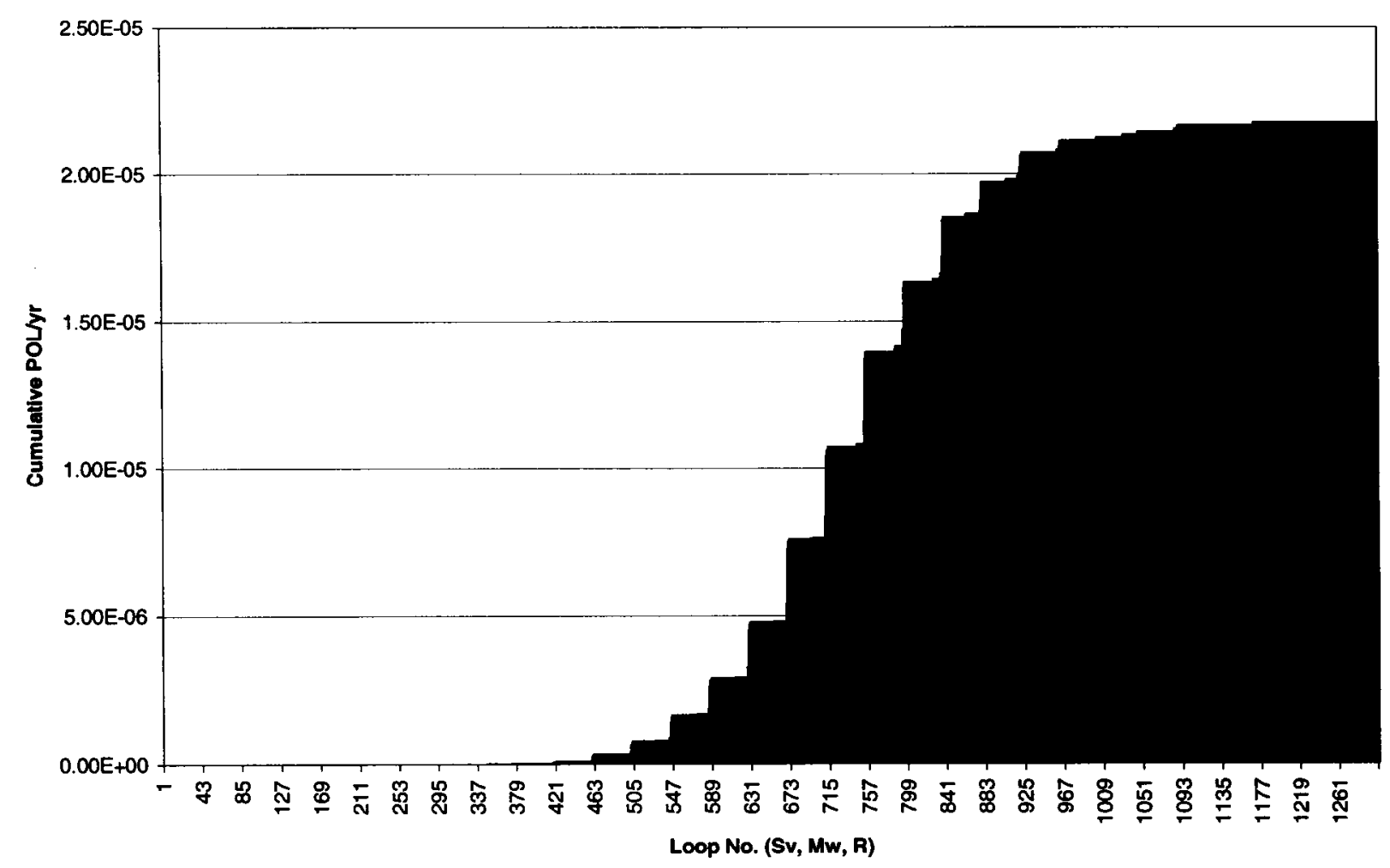

Figure 10. USGS PDCF Site Cumulative Probability of Liquefaction Summed by Loop 31 increasing $\mathrm{Sv}$ levels at $2.0 \mathrm{hz}, 6$ increasing $\mathrm{Mw}$ bins, and 7 increasing distance bins $\left(\mathrm{N}_{1}\right)_{60}$ Values Calculated Using CPTU Data

(Equation 1, see page 7) 


\section{Attachment A - Engineering Stratigraphy}

Information obtained from the field exploration has been used to establish the engineering stratigraphy for the subsurface (surface to about 180 feet in depth) for F-Area (WSRC, 2001) and at the Pit Disassembly and Conversion Facility (PDCF) (LawGibb, 2001). The subsurface engineering stratigraphy was determined from CPTU measurements including tip resistance, sleeve resistance, friction ratio, and pore pressure signatures, as well as correlation with adjacent soil borings. The layering system is based on observed changes in the CPTU measurements that correlate between CPTU soundings and nearby borings. The layer nomenclature was developed for mapping subsurface units across various parts of the SRS. It is only used to differentiate units based on similar engineering characteristics that can be mapped in the investigation area. A generalized cross section for the PDCF site is shown on Figure A1. Figure A1 illustrates how engineering layers at the PDCF correlate with geologic formations.

The layer nomenclature follows an alphanumeric system with layer numbers increasing from top to bottom. Subdivided layers are identified with a letter designation (e.g., TR1A). Some layer boundaries correspond to geologic formations. Layer TR1 is most probably the Altamaha formation. In fact, some upper portion of Layer 1A may also be Altamaha. However, due to the similar material properties and an irregular erosional surface that separates these units, defining the contact between the Altamaha and Tobacco Road formation is difficult. In some parts of the F-Area, the TR1 and TR2 layers have been subdivided to recognize sublayers with distinct soil properties (TR1A, TR2A, and TR2B). As described in the F-Area Geotechnical Characterization Report (WSRC, 1996), the TR3/4 layer was first correlated to the lower portion of the Tobacco Road formation but based on more recent geologic investigations in the area has been reassigned to the upper portion of the Dry Branch formation. Layers DB1 through DB3 were combined into a DB1/3 layer because of similar properties. Likewise, layers DB4 and DB5 were combined into a DB4/5 layer. The DB1/3 layer corresponds to the Dry Branch formation while the DB4/5 layer corresponds to the upper Santee/Tinker formation. The Santee/Tinker formation, is the most variable layer in the shallow subsurface. It has been further subdivided into the ST1 and ST2 layer where practical. The green clay, which is an informal stratigraphic interval at the SRS, is considered the basal unit for the shallow engineering stratigraphy and is labeled as GC. This geologic unit is locally continuous and provides a reliable marker bed. The Green Clay overlays the Congaree Formation which is predominantly dense silty sands.

The following sections describe the physical attributes used to delineate each layer, as well as, depositional environment and lithologic variability.

\section{TR1 Layer}

The TR1 layer is most probably the Altamaha formation consisting of red, purple and brown poorly sorted sands ranging from fine to gravel size with the dominant soil classification being clayey to silty sands (SC to SM). The depositional environment of these sediments is characterized as high energy fluvial such as river and stream channels. The base of the Altamaha is distinguished by an irregular erosional surface and can reach thicknesses of up to 70 feet at the SRS. The TR1 layer is characterized by moderate CPTU tip resistances and relatively high friction ratios. 


\section{TR1A and TR2A Layers}

The TR1A and TR2A layers have been used to differentiate the Tobacco Road formation. Sediments of the Tobacco Road formation were deposited in low energy shallow marine transitional environments such as tidal flats. Much of the sediments are laminated or otherwise bioturbated (mixed by burrowing organisms after deposition) red, purple and brown poorly sorted sands and clayey sands.

The TR1A, and TR2A layers are predominantly clayey sands and sands (SC/SM to SP-SC/SM) as determined by laboratory classification tests. The TR2A layer is distinguished from the overlying TR1A layer by increased tip resistance and notably lower sleeve friction values resulting in a lower friction ratio.

\section{TR2B, TR3/4, and DB1/3 Layers}

The Dry Branch Formation consists of sands and clays deposited in a transitional sequence between near shore and bay or lagoon environments. The upper contact of the TR2B layer is defined by an increase in tip resistances. The TR3/4 layer is defined by a marked decrease in CPTU tip resistance and an increase in both the friction ratio and pore pressure measurements. As determined by laboratory classification tests, the TR2B layer consists of sands with minor amounts of clay and silts (SP-SC/SM) and the TR3/4 layer is predominantly clays and sandy clays (SC).

The DB1/3 layers correspond to the Irwinton Sands. On the CPTU logs, the DB1/3 layer is a zone of variable, but generally high, CPTU tip resistances and low friction ratios. In general, pore pressures are low or slightly above hydrostatic. The dominant unified soil classification for the $\mathrm{DB} 1 / 3$ is SP-SM with minor layers of CL material occurring as laminations.

\section{DB4/5, ST1 and ST2 layers}

The Santee/Tinker Formations represent the most complex geologic unit in the shallow subsurface of F-Area. It is depositionally complex and highly variable in both its lithology and material properties. Soils in the Santee/Tinker range from sands to silty sands (SP-SM). The contact between the Santee/Tinker Formation and the overlying Dry Branch Formation is generally seen on the CPTU logs as a sharp decrease in the pore pressure measurement. This layer is characterized by thin, alternating layers of low and high CPTU tip resistances and friction ratios. Characteristically, CPTU soundings in this layer show a pronounced sawtooth trace with large variations over relatively small vertical intervals. This highly variable pattern suggests interfingering of alternating lenses of clayey and silty sands with more resistant, silica-cemented sediments and less resistant, calcareous sediments, and appears to be a result of rapid lateral and vertical changes in the nature of the materials originally deposited in this interval. The unit consists of complex sequences of limestones, carbonate muds, carbonate sands, and muddy sands.

The soils of the DB4/5 interval are much more plastic than the overlying Irwinton Sand (DB1/DB3) and the underlying ST1 layer. Soils of the DB4/5 typically classify as SM to CL materials. The DB4/5 layer has moderate to low tip resistances and moderate friction ratios. The DB4/5 layer has been subject to extensive characterization within the APSF area because of 
observed soft zones (tip resistances less than 15 tsf and N-values less than 5). The ST1 layer is characterized by higher tip resistances than the overlying DB4/5 layer underlying ST2 layer. Not all soundings penetrate this layer. Soils of the ST2 layer are generally characterized by lower tip resistances and sleeve resistances than the overlying ST1 layer. Soils of the ST1 and ST2 layers generally classify and SM to SP-SM materials.

\section{GC Layer}

The "green clay" (GC) is an informal stratigraphic name at SRS for stiff, green to gray clays, silts, and clayey sands that are commonly found at the base of the Santee/Tinker Formation. In general, these soils classify as SM to ML with varying amounts of clay. This layer is locally continuous at F-Area and has been used to define the lower boundary of the shallow stratigraphy. Layer elevations and thicknesses have been determined from those borings and soundings that penetrate this layer. Most borings and CPTU soundings do not reach or penetrate the GC layer. The top of the layer ranges from around El. 126 feet MSL in the south and northwestern portions of the area to a high of around 140 feet MSL in the east-central part of the area. This is consistent with the correlating Gordon Confining Unit as mapped by Aadland (1995) which corresponds to the "green clay" unit.

\section{References}

Aadland, R. K., Gellici, J. A., and Thayer, P. A., 1995. Hydrogeologic Framework of West-Central South Carolina, S. C. Department of Natural Resources, Water Resources Division, Report 5.

LawGibb, 2001. PDCF Geotechnical Report (Draft), June 2001.

WSRC 1996. F-Area Geotechnical Characterization Report, WSRC-TR-96-0069, Rev. 0, September 1996.

WSRC, 2001. Determination of Stratagraphic Tops for F and H Area Tobacco Road, Dry Branch and Santee Formations, K-CLC-G-00069, Rev. 1, January 2001. 


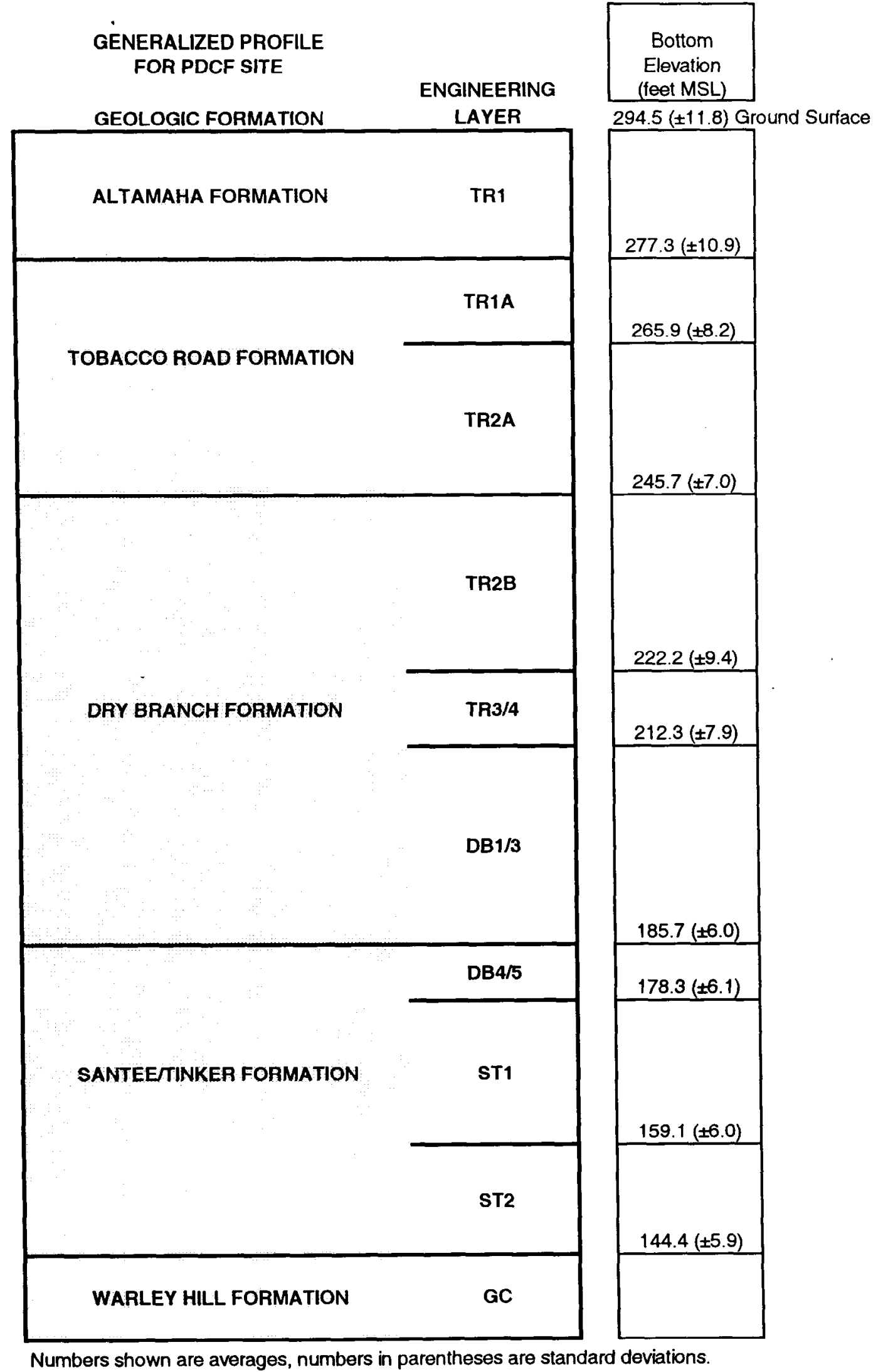

Figure A1. Generalized Cross Section for the PDCF Site 